\title{
PERANCANGAN DAN PENGEMBANGAN SISTEM ABSENSI REALTIME MELALUI METODE PENGENALAN WAJAH
}

\author{
I Nyoman Tri Anindia Putra ${ }^{1}$, Ida Bagus Gede Dwidasmara², \\ I Gede Santi Astawa ${ }^{3}$ \\ 1,2,3 Program Studi Teknik Informatika Jurusan Ilmu Komputer \\ Fakultas MIPA \\ Universitas Udayana Bukit Jimbaran Indonesia
}

\section{Email : trianindiaputra@gmail.com}

\begin{abstract}
Abstrak
Perancangan suatu aplikasi ataupun sistem pengenalan wajah yang baik sangat dibutuhkan dalam mengidentifikasi personal berdasarkan pengenalan wajah yang bisa dimanfaatkan kedalam sebuah sistem keamanan elektronik atau sistem absensi. Berdasarkan beberapa metode yang telah diteliti penulis ingin merancang dan mengembangkan sistem absensi melalui salah satu metode pengenalan wajah yang memiliki akurasi cukup baik berdasarkan beberapa penelitian sebelumnya, PCA (Principle Component Analysis) atau sering disebut dengan Eigenfaces ini merupakan metode yang multifungsi digunakan, karena Eigenfaces memilki banyak fungsi khususnya dalam pengenalan wajah seperti dapat melakukan prediksi, penghapusan redundansi, kompresi data, reduksi dimensi, sampai pada ekstraksi Ciri (Marti, 2009) sehingga penulis menggunakan metode eigenfaces sebagai metode yang akan digunakan dalam pengembangan sistem absensi realtime dalam pengenalan wajah tersebut dengan menambahkan metode pada pendeteksian wajah sehingga wajah dapat dideteksi secara realtime. Tujuan dari penulisan tugas akhir ini yaitu dapat mengembangkan dan mengimplemetasikan metode pengenalan wajah Eigenfaces atau PCA kedalam sistem absensi menggunakan deteksi wajah dan melakukan absen dengan menekan tombol absen secara real time serta mengintegerasikan sistem absensi dengan database. Sesuai dengan hasil pengujiannya dapat disimpulkan Sistem absensi yang telah dibuat mampu melakukan proses absensi kepada user secara realtime dengan mendeteksi wajah user melalui metode pengenalan wajah yaitu PCA(Priciple Component Analysis) dengan tingkat akurasi sebesar $90 \%$ melalui pengujian secara fungsional akan tetapi Akurasi pada sistem absensi melalui metode pengenalan wajah ini akan semakin buruk jika pencahayaan kurang atau lebih.
\end{abstract}

Kata Kunci : PCA (Principle Component Analysis), Eigenface

\begin{abstract}
The design of a good application or face recognition system is very important in identifying people based on face recognition that can be used in an electronic safety system or attendance record system. Based on some methods that have been studied the writer would like to design and develop an attendance record system through one of the face recognition methods that has a good
\end{abstract}


enough level of accuracy based on previous studies. PCA ( Principle Component Analysis) or more commonly called Eigenfaces is a multifunctional method, since Eigenfaces has many functions, particularly, in recognizing faces such as ability to predict, delete redundancies, data compression, dimension reduction and characteristics extraction ( Marti, 2009). Thus, the writer used Eigenfaces as a method to develop realtime attendance record system by adding to it a method of face recognition method to be able to detect faces in realtime. This final project was aimed at developing and implementing Eigenfaces or PCA into an attendance record detection and checking the attendance by pressing the attendance function in real time as well as integrating the attendance record system into the datebase. In accordance with the results of testing it can be concluded that the attendance record system that was created is able to do the attendance record process for the user in realtime by detecting the user's face through PCA (Principle Component Analysis) at $90 \%$ level of accuracy through the functional testing. However, The level of accuracy will get decrease if the light is lower or higher than required.

Keywords: PCA (Principle Component Analysis), Eigenface.

\section{PENDAHULUAN}

Perancangan suatu aplikasi ataupun sistem pengenalan wajah yang baik sangat dibutuhkan dalam mengidentifikasi personal berdasarkan pengenalan wajah yang bisa dimanfaatkan kedalam sebuah sistem keamanan elektronik atau sistem absensi. Pengenalan wajah dalam penelitian yang akan dilakukan adalah mengimplementasikan metode pengenalan wajah kedalam suatu sistem absensi, yang nantinya digunakan sebagai algoritma dalam pendeteksian wajah, yang sering disebut dengan sistem absensi wajah. Selain itu juga penelitian tentang pengenalan wajah ini dimotivasi oleh banyaknya aplikasi praktis tentang pengenalan wajah yang baik, yang dibutuhkan pada berbagai bidang baik itu bidang keamanan maupun dibidang akademik.

Banyaknya metode yang digunakan dalam penelitian tentang pengenalan wajah 2D dengan skala keabu-abuan (Grayscale) diantaranya yaitu pengenalan wajah menggunakan metode VFI5 dimana pada citra telah mengalami transformasi wavelet menghasilkan akurasi mencapai 90\% yang ditulis oleh Pramitasari (2009), selain itu pengenalan wajah dengan metode Eigenface dan Jaringan Saraf Tiruan (JST) yang ditulis oleh Mulyono,dkk(2012) menghasilkan akurasi sebesar $84,6 \%$, pengenalan wajah dengan beberapa metode diantaranya metode Eigenface, Laplacianface dan Orthogonal Laplacianfaces (OL) dimana masingmasing memiliki akurasi yaitu Eigenface sebanyak $\quad 87.50 \% \quad$ Laplacianface sebanyak $92.50 \%$ dan OL sebanyak $99.17 \%$ yang ditulis oleh Marti dan Soelaiman (2006).

Berdasarkan beberapa metode yang telah diteliti penulis ingin merancang dan mengembangkan sistem absensi melalui salah satu metode pengenalan wajah yang memiliki akurasi cukup baik berdasarkan beberapa penelitian sebelumnya, PCA (Principle Component Analysis) atau sering disebut dengan Eigenfaces ini merupakan metode yang multifungsi 
digunakan, karena Eigenfaces memilki banyak fungsi khususnya dalam pengenalan wajah seperti dapat melakukan prediksi, penghapusan redundansi, kompresi data, reduksi dimensi, sampai pada ekstraksi Ciri (Marti, 2009) sehingga penulis menggunakan metode eigenfaces sebagai metode yang akan digunakan dalam pengembangan sistem absensi realtime dalam pengenalan wajah tersebut dengan menambahkan metode pada pendeteksian wajah sehingga wajah dapat dideteksi secara realtime.

Berdasarkan dengan latar masalah yang telah dijelaskan di atas, maka dapat dirumuskan sebuah pokok permasalahan, yaitu

1. Bagaimana merancang sistem absensi menggunakan metode pengenalan wajah yaitu dengan metode PCA (Principle Component Analysis) atau Eigenfaces?

2. Bagaimana mengimplementasikan metode pengenalan wajah PCA (Principle Component Analysis) Eigenfaces kedalam sistem absensi wajah?

Adapun batasan masalah dari penelitian ini adalah:

1. Sistem hanya bisa melakukan proses absensi pada 1 orang saja pada setiap proses absensi.

2. Wajah hanya dapat dideteksi jika wajah tegak lurus atau wajah user dapat miring kekiri atau kenanan sebanyak 15 derajat dan berada didepan kamera $-+40 \mathrm{~cm}$.

3. Pencahayaan saat penyimpanan dan pengenalan wajah sangatlah penting dalam kondisi cukup, tidak kurang dan juga tidak berlebih, karena dapat menyebabkan program tidak berjalan seperti semestinya.

Tujuan dari penulisan tugas akhir ini yaitu dapat mengembangkan dan mengimplemetasikan metode pengenalan wajah Eigenfaces atau PCA kedalam sistem absensi menggunakan deteksi wajah dan melakukan absen dengan menekan tombol absen secara real time serta mengintegerasikan sistem absensi dengan database.

\section{PENELITIAN RELEVAN}

Berdasarkan penelitian yang ditulis oleh Marti (2009) dikatakan bahwa Metode Orthogonal Laplacianfaces lebih baik dibandingkan dengan Metode Laplacianfaces dan Eigenfaces. Hal ini dibuktikan dengan hasil penelitian pengenalan wajah dengan beberapa metode diantaranya metode Eigenface, Metode ini menghasilkan akurasi sebesar $87.50 \%$ sedangkan untuk sistem pengenalan wajah menggunakan metode Laplacianface menghasilkan akurasi sebesar $92.50 \%$ dalam pengenalan wajahnya, dan yang terakhir yaitu membuat sistem pengenalan wajah menggunakan metode Orthogonal Laplacianfaces (OL) memiliki tingkat akurasi sebesar $99.17 \%$ dalam melakukan proses pengenalan wajah.

Selanjutnya berdasarkan penelitian yang ditulis oleh Mulyono,dkk (2012) yaitu membuat sistem pengenalan wajah dengan menggunakan metode eigenfaces dalam mereduksi dimensi vector wajah menjadi vector yang lebih sederhana (Eigen Vector). Dimana eigen vector yang diperoleh digunakan oleh JST perambatan balik pada proses pelatihan dan pengenalan. Kemudian dilakukan proses pengujian 
menggunakan citra wajah yang belum pernah digunakan dalam proses pelatihan. Dan hasil penelitian menunjukan eigenfaces dan JST untuk pengenalan wajah dapat memberikan tingkat akurasi yang cukup baik. Dimana sistem mampu menghasilkan tingkat keberhasilan mencapai 84,6\%.

Selanjutnya Pramita (2009) melakukan penelitian dalam pembuatan sistem pengenalan wajah menggunakan metode VFI5 dimana pada citra foto tunggal dilakukan proses reduksi ukuran citra dengan menggunakan transformasi wavelet yang selanjutnya dilakukan pengenalan wajah menggunakan VF15 yaitu algoritma Voting Feature Interval. Algoritma VF15 ini merupakan suatu algoritma yang merepresentasikan deskripsi sebuah konsep oleh sekumpulan interval nilai-nilai fitur atau atribut dan menghasilkan akurasi mencapai $90 \%$.

Menurut Jogiyanto, H.M.(2001) diterangkan bahwa sistem adalah sekumpulan dari elemen yang berinteraksi untuk mencapai suatu tujuan tertentu.

Menurut Adi Nugroho,(2004) terdapat dua pendekatan di dalam mendefinisikan sistem. Pendekatan yang pertama lebih menekankan pada prosedurnya, bahwa suatu sistem adalah suatu jaringan kerja dari prosedur-prosedur yang saling berhubungan, berkumpul bersamasama untuk melakukan suatu kegiatan atau untuk menyelesaikan suatu sasaran tertentu. Sedangkan pendekatan yang kedua lebih menekankan pada elemennya, bahwa sistem adalah suatu urut-urutan operasi klerikal / tulis-menulis.
Menurut Adi Nugroho,(2005) sistem berorientasi obyek merupakan paradigma baru dalam rekayasa perangkat lunak yang memandang sistem sebagai kumpulan objek-objek diskrit yang saling berinteraksi. Yang dimaksud berorientasi obyek adalah bahwa mengorganisasikan perangkat lunak sebagai kumpulan obyek-obyek diskrit yang bekerja sama antara informasi atau struktur data dan perilaku yang mengaturnya. Obyek adalah segala sesuatu yang ada dialam, dimana obyek-obyeklah yang menyusun dunia ini. Setiap obyek mempunyai informasi-informasi atau atribut-atribut dan perilaku sebagai suatu operasi pengaturnya. Obyek-obyek yang mempunyai atribut dan operasi yang sama dapat dikelompokkan dalam sebuah kategori. Sebuah kategori untuk beberapa obyek disebut kelas.

Menurut Sholiq, (2006) Siklus pengembangan sistem berorientasi obyek dilukiskan pada gambar 2.1, Di bawah ini, yang mengandung pengembangan representasi obyek secara progresif dan mengandung tiga langkah utama, yaitu: analisis, perancangan, dan implementasi. Pada tahap awal pengembangan, model yang dikembangkan bersifat abstrak dan berfokus pada kualitas eksternal sistem. Kemudian melalui perkembangan model, menjadi semakin rinci, dan fokus bergeser ke bagaimana sistem akan dibangun dan bagaimana seharusnya berfungsi. Penekanan pada pemodelan biasanya terjadi saat analisis dan perancangan dan berfokus pada isu-isu konseptual. Dalam pengembangan sistem berorientasi obyek akan digunakan UML (Unified Modelling Language) sebagai alat bantunya. Pada 
tahap analisis, dikembangkan model dari aplikasi dunia nyata dengan memperlihatkan properti-properti yang penting. Model abstrak mengkonseptualisasikan aplikasi dan menjelaskan apa yang diharapkan dari sistem. Pada tahap perancangan obyek didefinisikan bagaimana analisis berorientasi aplikasi akan direalisasikan pada lingkungan implementasi. Saat perancangan sistem diusulkan arsitektur sistem secara keseluruhan yang mengorganisasi sistem ke dalam subsistem dan menyediakan konteks untuk membuat keputusan.

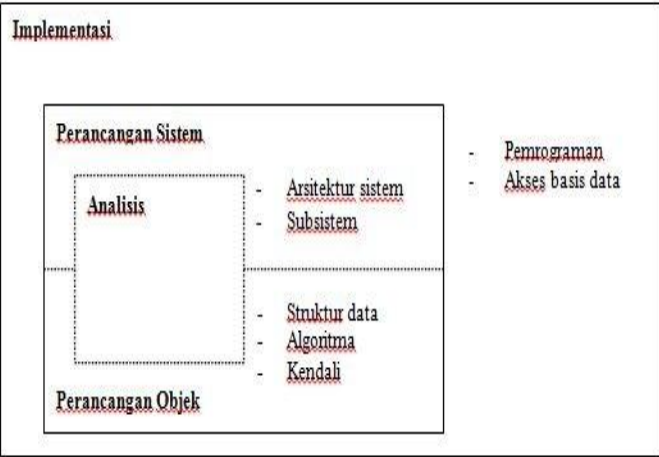

Gambar 2.1 Langkah Siklus

Pengembangan Sistem Berorientasi Obyek Sumber: Abdul Kadir (2001)

UML (Unified Modelling Language) adalah salah satu alat bantu yang sangat handal di dunia pengembangan sistem yang berorientasi objek. Hal ini disebabkan karena UML menyediakan bahasa pemodelan visual yang memungkinkan bagi pengembang sistem untuk membuat cetak biru atas visi mereka dalam bentuk yang baku, mudah dimengerti serta dilengkapi dengan mekanisme yang efektif untuk berbagi dan mengkomunikasikan rancangan mereka dengan yang lain.
UML menyediakan cukup banyak diagram yang dapat membantu mendefinisikan sebuah aplikasi, diagram-diagram tersebut seperti terlihat pada tabel

TabeL 1 Tipe Diagram UML Sumber Munawar (2005)

\begin{tabular}{|c|c|}
\hline Diagram & Inivan \\
\hline Use Case & 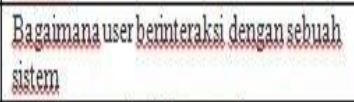 \\
\hline Activity & Prenlaku proseddual danparaxel \\
\hline Class & Class, fitur danrelasinva \\
\hline Package & Stroltur hienallik satkomplagi \\
\hline Collaboration & 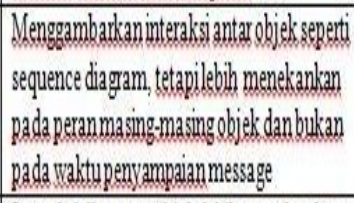 \\
\hline Sequence & 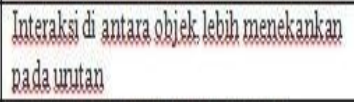 \\
\hline Component & Spuktur dankonkeksidan hemponen \\
\hline Deployment & 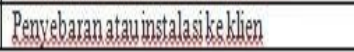 \\
\hline
\end{tabular}

Database merupakan himpunan kelompok data yang saling berkaitan. Data tersebut diorganisasikan sedemikian rupa agar tidak terjadi aplikasi yang tidak perlu sehingga dapat diolah atau dieksplorasi secara cepat dan mudah untuk menghasilkan informasi (Catur, 2013)

Menurut (Munir, 2010) metodologi pengembangan sistem adalah suatu proses yang digunakan untuk mengembangkan sistem informasi. Metodologi meliputi (1) aktivitas yang dilakukan pada setiap langkah (fase) (2) peranan individu dan kelompok dalam setiap aktivitas (3) deliverables dan standard kualitas bagi setiap aktivitas dan (4) peralatan ("tools") dan teknik yang digunakan untuk setiap aktivitas. pengembangan sistem menggunakan 
metodologi dilakukan untuk dapat memastikan pendekatan yang konsisten dalam setiap proyek, serta menghasilkan dokumentasi yang konsisten dan lengkap untuk setiap proyek. Citra adalah gambar dua dimensi yang dihasilkan dari gambar analog dua dimensi yang kontinu menjadi gambar diskrit melalui proses sampling. Gambar analog dibagi menjadi $\mathrm{N}$ baris dan $\mathrm{M}$ kolom sehingga menjadi gambar diskrit. Persilangan antara baris dan kolom tertentu disebut dengan piksel. Contohnya adalah gambar/titik diskrit pada baris $\mathrm{n}$ dan kolom $m$ disebut dengan piksel [n,m]. (Wikipedia)

Sampling adalah proses untuk menentukan warna pada piksel tertentu pada citra dari sebuah gambar yang kontinu. Pada proses sampling biasanya dicari warna rata-rata dari gambar analog yang kemudian dibulatkan. Proses sampling sering juga disebut proses digitisasi.

\begin{tabular}{lrr}
\multicolumn{2}{c}{ Pengolahan citra } & (Image \\
Processing) adalah bidang & yang \\
berhubungan dengan & proses \\
transformasi citra (image) & yang \\
bertujuan untuk mendapatkan kualitas & citra yang lebih baik (Fairhurst, 1988)
\end{tabular}

Pengenalan pola (Pattern Recognition) adalah bidang ilmu yang melakukan proses analisis gambar yang inputnya adalah gambar ataupun citra digital dan menghasilkan output suatu deskripsi dengan tujuan untuk mendapatkan informasi yang disampaikan oleh gambar atau citra, dengan kata lain meniru kemampuan manusia (Otak manusia ) dalam mengenali suatu objek atau pola tertentu (Fairhurst, 1988)

\section{HASIL DAN PEMBAHASAN \\ Perancangan}

Penelitian

Pengembangan Sistem Absensi Real Time Melalui Metode Pengenalan Wajah." ini penulis memiliki variable penelitian yang digunakan sebagai tolak ukur dari keberhasilan implementasi sistem ini yaitu apakah wajah user dapat dikenali oleh sistem dengan menggunakan metode pengenalan wajah sehingga proses absensi wajah dapat dilakukan.

\section{Tahap Perencanaan (Planning)}

Perencanaan bermanfaat untuk mendefinisikan ruang lingkup pengembangan sistem, identifikasi masalah, mengatur urutan tugas dalam pengembangan sistem serta pengendaliannya. Pada tahap ini akan dilakukan indentifikasi masalah dan tujuan yang ada, sebelum mengembangkan sistem absensi realtime menggunakan metode pengenalan wajah. Tahapan ini penting dilakukan untuk mengetahui data atau fakta pada sistem pengenalan wajah. Adapun teknik yang akan dipakai dalam pengumpulan data atau fakta adalah teknik kajian pustaka. Tujuan dari teknik ini adalah untuk mendapatkan referensi sebagai pedoman untuk pembangunan sistem yang akan digunakan. Langkahlangkah yang dilakukan dalam teknik kajian pustaka ini mencari dan mempelajari referensi-referensi yang digunakan dalam penelitian. Referensireferensi tersebut adalah referensi mengenai :

- Metodologi pengembangan sistem dalam hal ini adalah metodelogi SDLC. 
- Algoritma yang dapat digunakan untuk mengenali wajah dalam hal ini seperti Algoritma Orthogonal Laplacianfaces, Eigenfaces, Fisherfaces, SVM, Nearestneighbor, JST,Fisherfaces.

- Algoritma PCA untuk melakukan reduksi dimensi pada citra dan menghasilkan eigenfaces

\section{Tahap Analisis Sistem}

Tahapan ini dilakukan dengan menganalisis kebutuhan sistem. Perangkat dan teknik-teknik tertentu akan membantu menganalisis penetuan kebutuhan. Perangkat yang dimaksud adalah penggunaan diagram aliran data untuk menyusun daftar input, proses dan output dari sistem pengenalan wajah yang akan dikembangkan. Hasil dari tahapan ini adalah spesifikasi kebutuhan sistem dan analisa dari model proses sistem yang berupa :

- Penentuan input-input dari Sistem Absensi Wajah.

- Penentuan proses-proses yang terjadi atau terlibat dalam pengoperasian Sistem Absensi Realtime dengan Menggunakan Metode Pengenalan Wajah.

- Penentuan output yang dihasilkan dari pemrosesan input pada Sistem

Absensi Wajah

Pada tahap ini juga didefinisikan kebutuhan-kebutuhan user dalam penggunaan sistem, termasuk output yang diharapkan oleh user dalam penggunaan sistem. Adapun kebutuhan user dalam penggunaan sistem yaitu

- Sistem absensi yang dibutuhkan adalah sistem absensi realtime dengan menggunakan metode pengenalan wajah
- Sistem dapat digunakan dengan mudah (gampang dimengerti)

- Sistem dapat melakukan absensi dengan menggunakan pendeteksian wajah.

- Sistem absensi dapat digunakan oleh user yang wajahnya sudah di training.

- Sistem dapat melakukan rekapitulasi absensi kedalam Mirosoft Excel

Input yang digunakan adalah gambar wajah yang diambil dari user itu sendiri melalui webcam yang kemudian diproses dan menghasilkan output yang menampilkan foto beserta data dari user itu sendiri.

Secara umum Fitur-fitur yang akan dibangun dalam sistem absensi wajah ini diantaranya:

1. Sistem dapat melakukan absensi dengan menggunakan wajah dari user itu sendiri.

2. Sistem absensi dapat melakukan absensi wajah secara real time maksudnya secara langsung dan tepat waktu saat mengklik button Absen In maupun Absen Out.

3. Sistem dapat menampilkan rekapitulasi absen dari user selama bulan berjalan.

\section{Desain Sistem}

Pada tahapan ini dilakukan perancangan alur logika sistem yaitu dengan membuat Aktivitas Diagram sistem yang bertujuan untuk membuat suatu alur logika sistem Absensi Wajah mulai dari pemrosesan input menjadi output yang akan dihasilkan. Desain sistem yang akan dibuat dapat dilihat pada diagram Use case pada gambar 1 . 


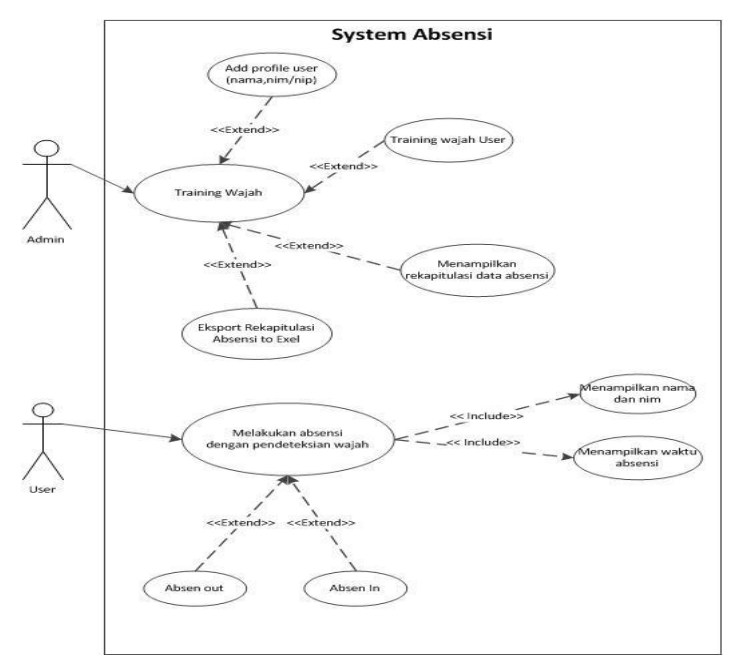

Gambar 1 Use Case

Diagram use case diatas menjelaskan apa saja yang dapat dilakukan oleh sistem dengan user/pembaca sebagai aktor utamanya. Inti dari sistem Absensi wajah ini adalah Pembentukan Feature yang akan diklasifikasikan dengan database yang ada, dimana pada use case ini proses pembentukan feature pada citra yang di test di klasifikasi terhadap database guna mendapatkan hasil. Untuk menggambarkan proses-proses yang terjadi di dalam sistem saat melakukan proses pengenalan wajah dapat digambarkan dalam suatu Aktivitas Diagram sistem. Adapun Aktivitas Diagram dari use case ini dapat dilihat pada gambar 2 .

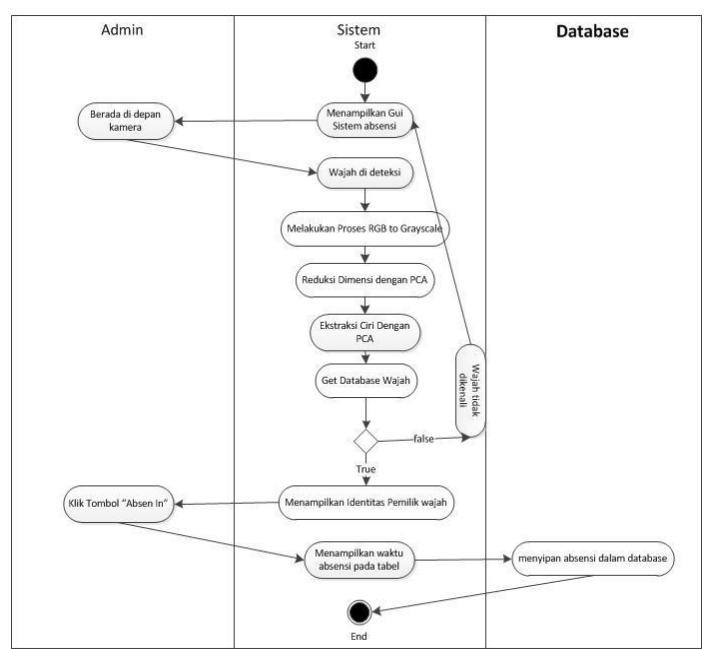

Gambar 2 Aktivitas Diagram User

Penjelasan dari Aktivitas Diagram User pada gambar 2 adalah sebagai berikut:

1. Yang pertama yaitu sistem akan menampilkan GUI dari Sistem Absensi Wajah,

2. Yang kemudian dilanjutkan dengan menampakan wajah user yang berada didepan kamera webcam.

3. Selanjutnya sistem akan langsung melakukan proses deteksi wajah, sampai pada pengklasifikasian dengan database yang sudah ada.

4. Apabila gambar tidak ada di dalam database atau tidak dikenali maka akan memasuki tahap false atau data invalid sehingga muncul pesan data invalid dan kembali ke interface awal

5. Apabila true, Menampilkan identitas pemilik wajah.

6. User mengklik tombol absen in jika ingin absen masuk dan tombol absen out jika ingin absen keluar.

7. Kemudian data absensi akan secara otomatis disimpan dalam database. Dan menampilkan waktu absen saat mengklik tombol absen. 


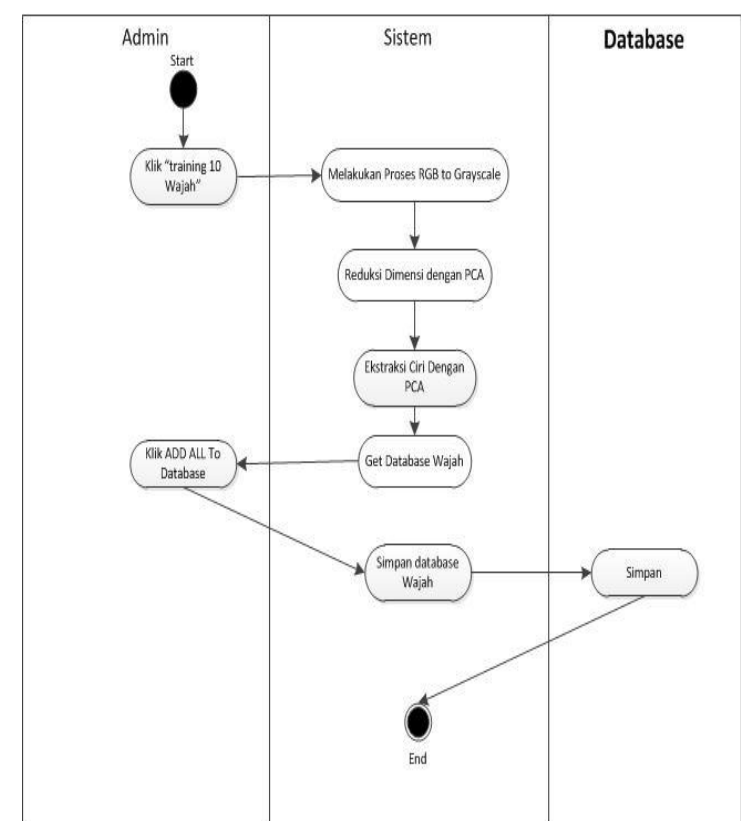

Gambar 3 Diagram Aktivitas Admin

Pada diagram aktivitas admin yang ada pada gambar 3.3 menjelaskan alur bagaimana admin mendapatkan database berupa fiture wajah yaitu :

1. Admin akan langsung melakukan training wajah dengan mengklik training 10 wajah sekali klik

2. Kemudian sistem akan melakukan proses pendeteksian wajah kemudian melakukan proses $R G B$ to Grayscale pada foto yang dimasukan.

3. Dan secara otomatis sistem langsung melakukan proses reduksi dimensi untuk mempercepat proses komputasi.

4. Kemudian admin akan langsung menyimpan database wajah dalam bentuk xml dan foto akan disimpan dalam folder serta menyimpan identitas user pada database mysql dengan sekali klik yaitu add all to database.

5. Training telah selesai dilakukan.

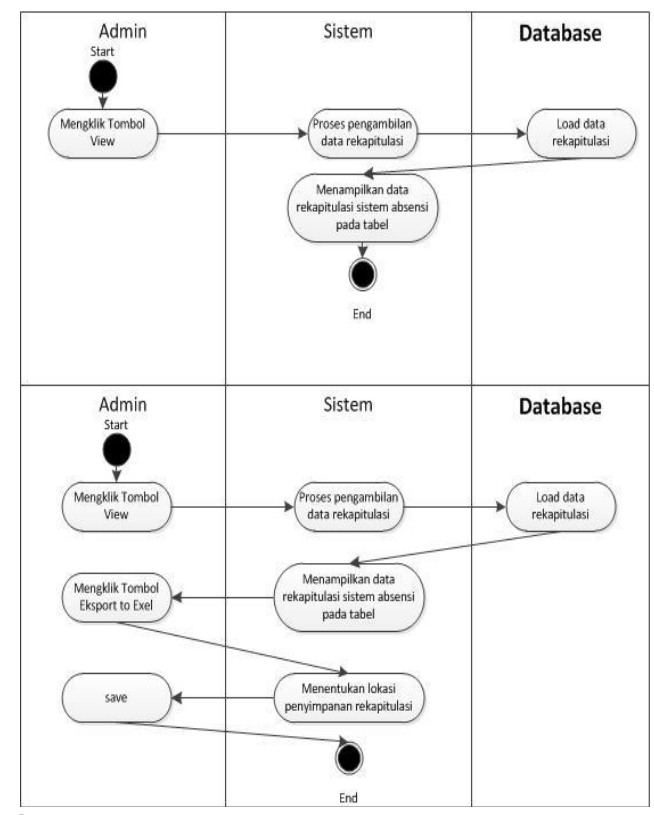

Gambar 4 Diagram Aktivitas View rekapitulasi absensi dan export to Excel

Pada gambar 4 dijelaskan bagaimana admin melakukan proses view rekapitulasi absensi dan eksport to Microsoft Excel.

1. Admin akan langsung mengklik tombol view

2. Selanjutnya sistem akan mengambil rekapitulasi absensi pada database

3. Setelah itu akan ditampilkan pada table data grid view

4. Jika ingin langsung meng eksport ke dalam Excel cukup dengan mengklik button export to Excel makan akan muncul tampilan menu save dan dapat menentukan posisi laporan ingin disimpan kemudian tekan enter.

Pada sistem absensi wajah ini data training wajah akan disimpan dalam 1 folder yang kemudian akan diklasifikasikan dengan wajah user yang akan melakukan proses absensi, 
sedangkan untuk penyimpanan absensi tetap menggunakan Database mysql.

Selanjutnya adalah design class diagram pada sistem absensi realtime dengan menggunakan metode pengenalan wajah didasari oleh pembuatan use case dapat dilihat pada gambar 5 .

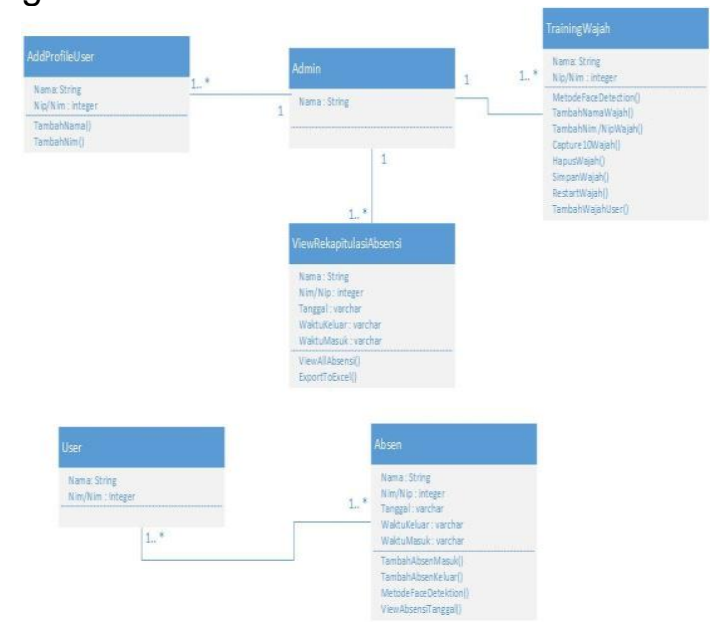

Gambar 5 Class Diagram

Setelah Pembuatan Class Diagram dilanjutkan dengan pembuatan sequence diagram dimana sequence diagram bertujuan untuk memberikan gambaran detail dari setiap use case diagram yang dibuat sebelumnya. sequence diagram pada saat training wajah dapat dilihat pada gambar 3.6 .

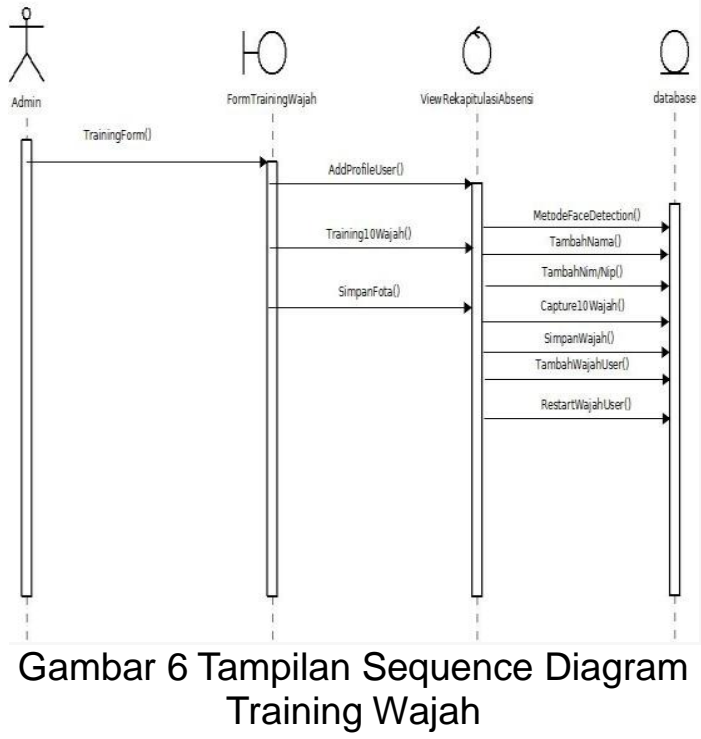

Pada sequence diagram diatas menjelaskan alur admin melakukan proses training wajah kepada user dimana yang pertama dilakukan adalah mengklik menu training wajah kemudian admin menginputkan nama dan nim/nip dari user, kemudian admin akan melakukan training wajah kepada user, dimana user sudah berada di depan kamera, selanjutnya hasil dari training wajah akan disimpan dalam database wajah, dan profile nama dan nim akan disimpan dalam database dalam mysql, selain itu juga admin dapat melakukan penambahan koleksi wajah user, serta restat wajah user jika image yang di capture saat training kurang jelas. 


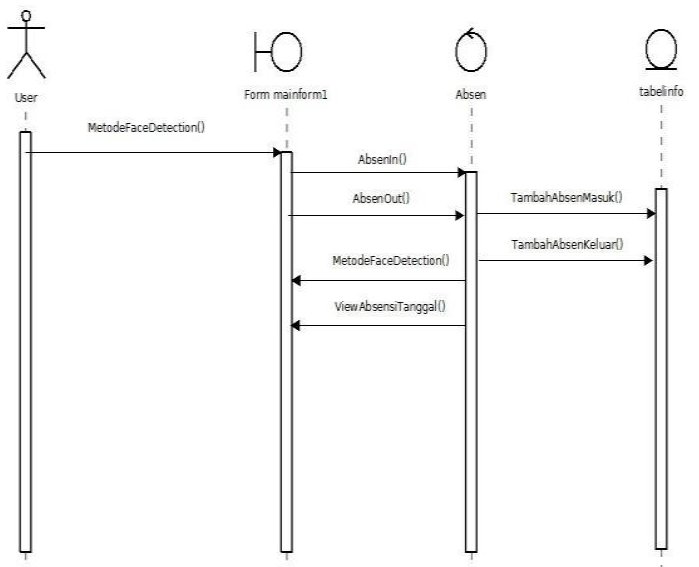

Gambar 7 Sequence Diagram Absensi

Pada sequence diagram pada gambar 7 menjelaskan alur dari user melakukan proses absensi dimana saat user berada didepan kamera wajah user akan langsung di deteksi, setelah dikenali maka user dapat melakukan absen in jika ingin absen masuk atau absen out jika ingin absen keluar, dimana setelah melakukan proses absen in maupun out maka secara otomatis data absensi waktu masuk maupun keluar ada tersimpan dalam database yang selanjutnya sistem akan menampilkan view absensi melalui table absen yang ada dalam sistem absensi.

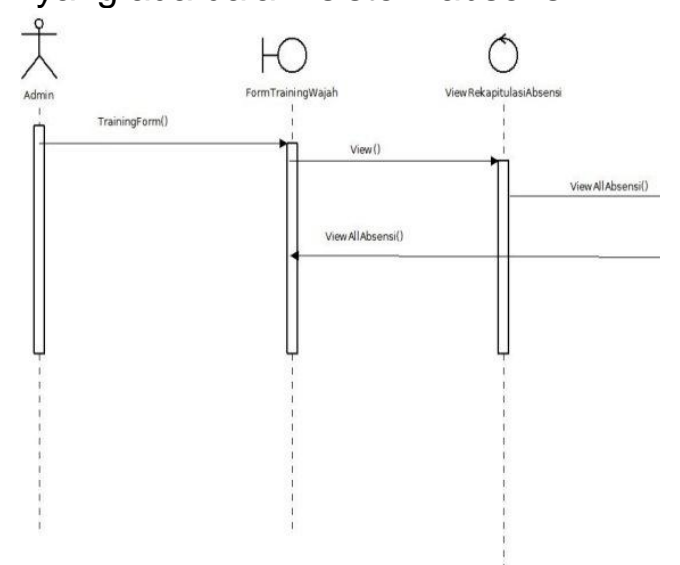

Gambar 8 Sequence diagram

Rekapitulasi absensi
Pada sequence diagram pada gambar 8, menjelaskan bagaiman admin melihat rekapitulasi absen, yang pertama admin akan melakukan klik button view yang kemudian sistem akan menampilkan data absensi pada table yang ada pada sistem.

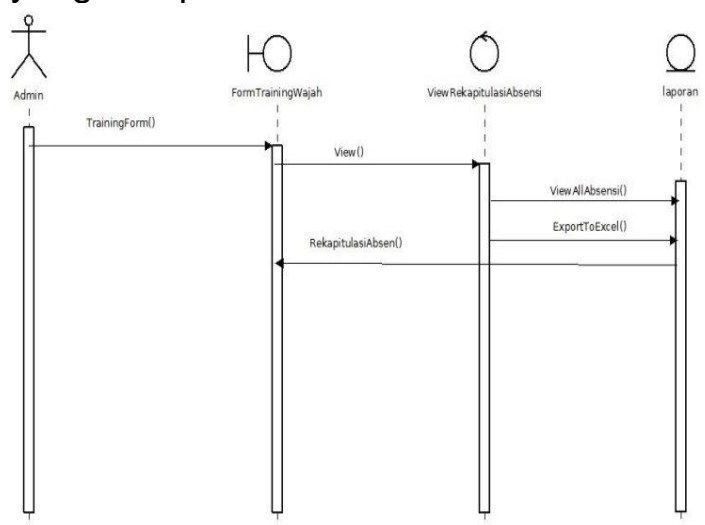

Gambar 9 Sequence Diagram Export to Excel

Pada sequence diagram 9 dijelaskan proses admin melakukan export database rekapitulasi absensi kedalam Microsoft excel dengan cara yang sama dengan menampilkan view rekapitulasi absensi, setelah terlihat di table rekapitulasi absen pada sistem admin dapat mengklik export to excel yang kemudian akan sistem akan secara langsung menampilkan form penyimpanan hasil export sesuai keinginan admin, setelah itu tekan save dan export dapat dilihat pada tempat dimana rekapitulasi absensi disimpan. Adapun database yang akan digunakan dalam sistem absensi ini berikut ERD yang akan digunakan dapat dilihat pada gambar 10. 


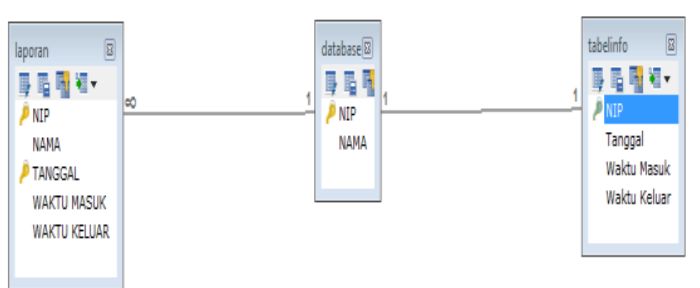

Gambar 10 Entity Relationship Diagram

Pada sistem absensi realtime dengan menggunakan metode pengenalan wajah ini ditunjang dengan database dengan 3 tabel diantaranya tabel laporan, tabel database, dan tabelinfo dimana masing masing dari tabel ini memiliki fungsi yaitu tabel database berfungsi untuk menyimpan semua profile dari user dimana terdapat nama dan nip sebagai primary key. Selanjutnya tabel info bertujuan untuk menampilkan data absensi masuk maupun keluar pada saat tanggal user melakukan absen, dan yang terakir tabel laporan yang bertujuan untuk menampilkan semua rekapitulasi absen selama bulan berjalan.

Tahapan yang terakhir yang dilalui adalah tahap perancangan antarmuka sistem yaitu dengan perancangan (GUI/Graphical User Interface). Dalam perancangan GUI terdapat beberapa hal yang menjadi pertimbangan penulis yaitu bagaimana merancang bentuk dari program sistem yang mudah dijalankan, cepat dan tidak terlalu memberatkan kinerja computer yang digunakan.

\section{Tahap Coding dan Dokumentasi Sistem}

Pada tahapan ini dilakukan implementasi hasil dari perancangan sistem ke dalam baris-baris kode program sehingga dapat dimengerti oleh mesin. Dalam tahap pengembangan sistem ini komponen-komponen pendukung yang digunakan yaitu:

- Platform yang akan digunakan untuk membangun Sistem Absensi Wajah yang akan dikembangkan menggunakan OpenCV

- Menggunakan

Bahasa pemrograman visual $\mathrm{C \#}$

Hal-hal yang dilakukan dalam tahap Coding adalah:

- Mengimplementasikan

perancangan ke dalam kode program dengan menggunakan bahasa pemrograman yang dapat dikaitkan dengan OpenCV

- Mengimplementasikan peracangan antar muka. Pada langkah ini dilakukan pembuatan interface sistem dengan visual studio 2010

Dalam tahap dokumentasi dibuat segala keterangan mengenai rancang bangun sistem. Dengan adanya dokumentasi diharapkan akan membantu dalam pengembangan sistem jika seandainya akan dilakukan pengembangan sistem lebih lanjut. Adanya dokumentasi juga akan memudahkan dalam penggunaan sistem jika ditemukan masalah dalam pengoperasiannya nanti sehingga pengguna mempunyai pedoman dalam menggunakan sistem.

\section{Tahap Pengujian Sistem}

Menurut Pressman (2007), pengujian perangkat lunak adalah elemen kritis dari jaminan kualitas perangkat lunak dan merepresentasikan kajian pokok dari spesifikasi,desain, dan pengkodean. Tujuan dari uji coba adalah mendesain serangkaian tes yang secara sistematis mengungkap beberapa jenis kesalahan yang berbeda 
dan melakukannya dalam waktu dan usaha yang minimum. Pendekatan pengujian yang digunakan untuk uji coba Sistem Absensi Wajah yaitu dengan pengujian Black-box yang didasarkan pada mengamati hasil eksekusi melalui data uji dan memeriksa fungsional dari perangkat lunak. Black box testing berfokus pada kebutuhan fungsional pada software, berdasarkan pada spesifikasi kebutuhan dari software. Black box testing bukan teknik alternatif daripada white box testing. Selain itu juga merupakan pendekatan pelengkap dalam mencakup error dengan kelas yang berbeda dari metode white box testing. Black box testing melakukan pengujian tanpa pengetahuan detil struktur internal dari sistem atau komponen yang dites. juga disebut sebagai behavioral testing, specification-based testing, input/output testing atau functional testing

Selain menggunakan pengujian black box penulis juga menggunakan pengujian fungsional bertujuan untuk memastikan bahwa kebutuhan kebutuhan telah dipenuhi dalam pengembangan sistem absensi realtime menggunakan metode pengenalan wajah, dan pada pengujian fungsional ini tidak berkonsentrasi pada proses yang terjadi namun hasil dari proses, adapun beberapa parameter yang digunakan dalam pengujian fungsional

- Sistem mampu melakukan proses absensi menggunakan metode pengenalan wajah secara realtime.

- Sistem Absensi Mampu melakukan Pendeteksian wajah

- $\quad$ Sistem dapat melakukan registrasi nama dan nim dan menyimpan kedalam database.
- $\quad$ Sistem absensi dapat melakukan penyimpanan data absensi

- Sistem dapat menampilkan rekapitulasi absensi

- Sistem dapat mengekspor rekapitulasi absensi kedalam Microsoft Excel

Dan yang terakhir adalah memasukan parameter pada pengujian fungsional kedalam scenario pengujian yang nantinya akan menghasilkan tingkat akurasi dari sistem absensi realtime dengan formula (Akurasi = jumlah percobaan benar/ jumlah total percobaan *100\%) dalam tahap ini yaitu pertama user akan melakukan registrasi pada sistem absensi dengan memasukan nama dan nim/nip yang kemudian wajah user akan di training sebanyak 20 sampel foto dengan ekspresi yang bervariasi. kemudian user akan langsung melakukan test absensi apakah user tersebut dapat dikenali atau tidak, selanjutnya pada scenario pengujian yang kedua proses dalam menampilkan seluruh rekapitulasi absensi serta mengeksportnya kedalam Microsoft Excel, sampai pada melakukan analisis sistem yang akan dibuat.

\section{Tahap Implementasi dan Evaluasi Relevansi Sistem}

Pada tahapan ini dilakukan uji coba secara Black box, kebutuhan fungsional, dan scenario pengujian yang nantinya dijadikan sebagai parameter dalam menentukan tingkat keberhasilan sistem absensi yang akan dibuat. 


\section{HASIL DAN PEMBAHASAN}

Aplikasi ini dibuat dengan bahasa pemrograman $\mathrm{C \#}$ dan dikombinasikan dengan penggunaan Library OpenCV untuk mempermudah digunakan Wrapper yaitu EmguCV. Untuk tampilan antar mukanya dibuat menggunakan Visual Studio 2010 dan Design sistem ini dibuat untuk mempermudah user dalam mengoperasikan system absensi wajah ini. Sistem Absensi Wajah ini juga menggunakan Mysql sebagai databasenya dimana setiap proses absensi maka secara langsung data absen akan disimpan kedalam database yang telah dibuat. Sistem yang dibuat ini merupakan system berbasis desktop, dimana Proses - proses dalam menjalankan system dibuat secara realtime dan mudah dipahami dalam penggunaannya. Sistem ini dibuat sedemikian rupa agar mudah dalam penggunaannya serta dapat digunakan yang sesuai dengan kebutuhan pengguna. Gambar 3.11 merupakan tampilan antarmuka dari system absensi wajah.

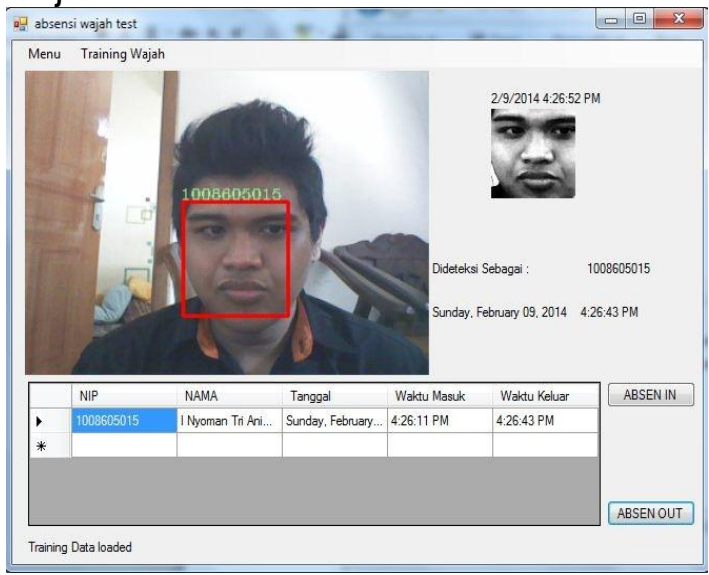

Gambar 11 Tampilan Utama dari sistem absensi wajah
Tampilan antarmuka diatas merupakan tampilan utama system absensi wajah, yang mana user hanya perlu menekan tombol "absen in " untuk absensi masuk dan "absen out" untuk absensi keluar. Sebelum menekan tombol, pengguna harus duduk didepan kamera / webcam untuk pendeteksian wajah, sebelum itu wajah pengguna harus di training terlebih dahulu, kemudia dimasukan kedalam database, setelah terdeteksi pengguna dapat melakukan absen in dengan menekan tombol "absen in" setelah menekan tombol absen in akan menampilkan identitas dari pengguna dan waktu pengguna melakukan absen. Hal yang sama juga pada tombol absen out.

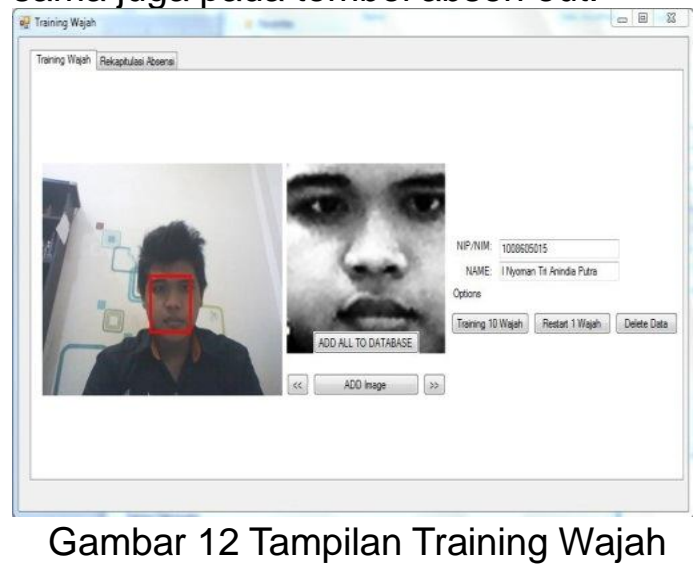

Pada antarmuka gambar 12 merupakan tampilan untuk antarmuka training wajah dimana, mengisikan text box nim/nip, dan nama, yang kemudian pengguna bias duduk di depan camera yang secara otomatis mendeteksi wajah lalu menekan tombol Training 10 wajah secara langsung dan kemudian akan muncul tombol "ADD ALL TO DATABASE" dan menekan tombol add all to database. Dan jika pengguna ingin menambahkan wajah training dari user dapat menekan tombol add image 
dimana pengguna tetap berada di depan kamera. Dan jika ingin mengulang training wajah sebanyak 10x atau lebih dapat menekan tombol restart 1 wajah. Atau jika ingin menghapus semua data wajah dapat dengan menekan tombol delete data.

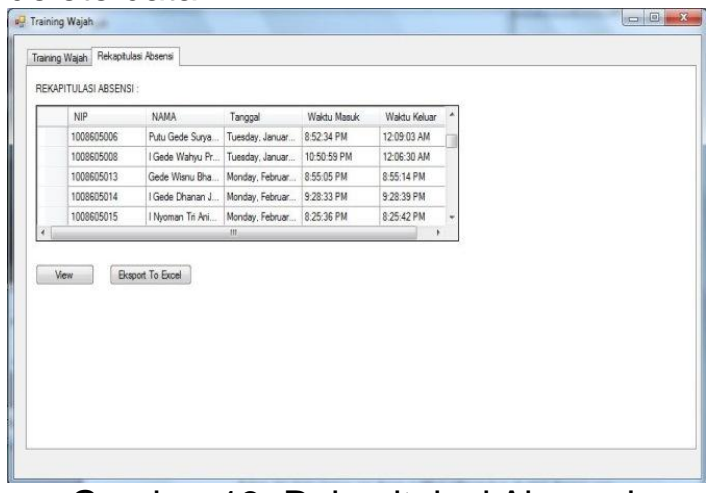

Gambar 13 Rekapitulasi Absensi

Selain itu juga pada gambar 4.6 system ini dapat melihat rekapitulasi absensi dengan cara menekan tombol view design antarmuka. Dan rekapitulasi dapat di export kedalam Excel untuk memudahkan proses pembuatan laporan.

\section{Pengujian Fungsional}

Pengujian fungsional bertujuan untuk memastikan bahwa kebutuhan kebutuhan telah dipenuhi dalam pengembangan sistem absensi realtime menggunakan metode pengenalan wajah, dan pada pengujian fungsional ini tidak berkonsentrasi pada proses yang terjadi namun hasil dari proses, adapun beberapa parameter yang digunakan dalam pengujian fungsional dan akan langsung di uji pada scenario pengujian

Berdasarkan Pengujian yang telah dilaksanakan secara fungsional dengan 6 parameter dilakukan 10x pengujian terhadap 10 user yang berbeda dan 2 dinyatakan tidak dapat di deteksi yaitu pada user ke 4 dan user ke 8 dimana pada user ke 4 pendeteksian wajah tidak dapat dideteksi hal ini dikarenakan pencahayaan yang terlalu terang sehingga tidak termasuk dalam kesalahan sistem internal melainkan factor eksternal, sedangkan pada user ke 8 wajah user tidak dapat dikenali hal ini dikarenakan wajah user memiliki kemiripan terhadap wajah user yang lain oleh karena itu wajah yang dikenali bukan user itu sendiri melainkan wajah orang lain. sehingga dapat disimpulkan tingkat akurasi dari sistem ini dalam pendeteksian wajah adalah jumlah percobaan berhasil/jumlah percobaan ${ }^{*} 100 \%$ Sehingga diperoleh hasil dari $9 / 10 * 100 \%=90 \%$

TabeL 4 Pengujian Fungsional

\begin{tabular}{|l|l|l|l|l|l|l|l|l|l|l|}
\hline Kebutuhan Fungsional & $\begin{array}{l}\text { User } \\
1\end{array}$ & $\begin{array}{l}\text { User } \\
2\end{array}$ & $\begin{array}{l}\text { User } \\
3\end{array}$ & $\begin{array}{l}\text { User } \\
4\end{array}$ & $\begin{array}{l}\text { User } \\
5\end{array}$ & $\begin{array}{l}\text { User } \\
6\end{array}$ & $\begin{array}{l}\text { User } \\
7\end{array}$ & $\begin{array}{l}\text { User } \\
8\end{array}$ & $\begin{array}{l}\text { User } \\
9\end{array}$ & $\begin{array}{l}\text { User } \\
10\end{array}$ \\
\hline $\begin{array}{l}\text { Sistem absensi dapat } \\
\text { melakukan proses } \\
\text { absensi dengan } \\
\begin{array}{l}\text { menggunakan metode } \\
\text { pengenalan wajah }\end{array}\end{array}$ & $\sqrt{ }$ & $\sqrt{ }$ & $\sqrt{ }$ & $\sqrt{ }$ & $\sqrt{ }$ & $\sqrt{ }$ & $\sqrt{ }$ & $X$ & $\sqrt{ }$ & $\sqrt{ }$ \\
\hline $\begin{array}{l}\text { Sistem Absensi } \\
\text { Mampu melakukan }\end{array}$ & $\sqrt{ }$ & $\sqrt{ }$ & $\sqrt{ }$ & $\mathrm{X}$ & $\sqrt{ }$ & $\sqrt{ }$ & $\sqrt{ }$ & $\sqrt{ }$ & $\sqrt{ }$ & $\sqrt{ }$ \\
\hline
\end{tabular}




\begin{tabular}{|l|l|l|l|l|l|l|l|l|l|l|}
\hline $\begin{array}{l}\text { Pendeteksian posisi } \\
\text { wajah }\end{array}$ & & & & & & & & & & \\
\hline $\begin{array}{l}\text { Sistem absensi dapat } \\
\text { melakukan } \\
\text { penyimpanan data } \\
\text { absensi }\end{array}$ & $\sqrt{ }$ & $\sqrt{ }$ & $\sqrt{ }$ & $\sqrt{ }$ & $\sqrt{ }$ & $\sqrt{ }$ & $\sqrt{ }$ & $\sqrt{ }$ & $\sqrt{ }$ & $\sqrt{ }$ \\
\hline $\begin{array}{l}\text { Sistem absensi dapat } \\
\text { melakukan proses } \\
\text { registrasi nama dan } \\
\text { nim serta menyimpan } \\
\text { kedalam database }\end{array}$ & $\sqrt{ }$ & $\sqrt{ }$ & $\sqrt{ }$ & $\sqrt{ }$ & $\sqrt{ }$ & $\sqrt{ }$ & $\sqrt{ }$ & $\sqrt{ }$ & $\sqrt{ }$ & $\sqrt{ }$ \\
\hline $\begin{array}{l}\text { Sistem absensi dapat } \\
\text { melakukan export } \\
\text { rekapitulasi absensi } \\
\text { kedalam Microsoft } \\
\text { Excel }\end{array}$ & $\sqrt{ }$ & $\sqrt{ }$ & $\sqrt{ }$ & $\sqrt{ }$ & $\sqrt{ }$ & $\sqrt{ }$ & $\sqrt{ }$ & $\sqrt{ }$ & $\sqrt{ }$ & $\sqrt{ }$ \\
\hline $\begin{array}{l}\text { Sistem absensi dapat } \\
\text { menampilkan } \\
\text { rekapitulasi absensi. }\end{array}$ & $\sqrt{ }$ & $\sqrt{ }$ & $\sqrt{ }$ & $\sqrt{ }$ & $\sqrt{ }$ & $\sqrt{ }$ & $\sqrt{ }$ & $\sqrt{ }$ & $\sqrt{ }$ & $\sqrt{ }$ \\
\hline
\end{tabular}

\section{Analisa Sistem Absensi}

Di lihat dari hasil uji coba yang dilakukan dengan menggunakan pengujian fungsional didapatkan hasil akurasi sebesar $90 \%$. pengembangan sistem absensi real time melalui metode pengenalan wajah ini berhasil di rancang dan dikembangkan dengan baik berdasarkan pengujian secara fungsional serta program berjalan dengan baik berdasarkan pengujian secara blackbox berdasarkan kebutuhan user yang telah dibuat sebelumnya, dan secara scenario percobaan dengan menggunakan metode pengenalan wajah. Namun akurasi pada sistem absensi melalui metode pengenalan wajah ini akan semakin buruk jika citra wajah yang di-training memiliki banyak kesamaan. Hal ini dapat dilihat saat melakukan uji coba yang ketiga, selain itu juga pencahayaan saat melakukan absensi maupun saat melakukan training wajah sangatlah penting dalam kondisi cukup, tidak kurang dan juga tidak berlebih, karena dapat menyebabkan program tidak berjalan seperti semestinya sebagai contohnya wajah tidak akan terdeteksi apabila pencahayaan terlalu terang. Selain itu pada saat face recognition dilakukan menggunakan webcam, sebaiknya tidak terlalu banyak gangguan di belakang pengguna (noise).

\section{PENUTUP}

Kesimpulan yang dapat diambil dari penelitian pada sistem absensi real time melalui metode pengenalan wajah ini adalah sebagai berikut:

1. Sistem absensi yang telah dibuat mampu melakukan proses absensi kepada user secara realtime dengan mendeteksi wajah user melalui 
metode pengenalan wajah yaitu PCA(Priciple Component Analysis) dengan tingkat akurasi sebesar $90 \%$ melalui pengujian secara fungsional akan tetapi Akurasi pada sistem absensi melalui metode pengenalan wajah ini akan semakin buruk jika citra wajah yang di-training memiliki banyak kesamaan.

2. Untuk kedepannya penelitian ini dapat dijadikan sebagai acuan dalam mengembangkan sistem absensi dengan menggunakan metode pengenalan wajah lainya seperti fisherface, iris mata dan penggunaan citra lainya.

3. Perancangan dan pengembangan sistem absensi realtime melalui metode pengenalan wajah dapat di rancang dan di uji dengan baik melaui 3 pengujian yaitu pengujian

DAFTAR PUSTAKA

Abdul Kadir (2001). Konsep Dan Tuntunan Praktis Basis Data, Andi Offset, Yogyakarta.

Adi Nugroho (2004). Konsep Pengembangan Sistem Basis Data, Edisi pertama, Informatika,Bandung.

Adi Nugroho (2005). Analisis Dan Perancangan Sistem Informasi Dengan

Metodologi

Berorientasi Objek, Informatika, Bandung.

Adrian, M. (2011). Perancangan Program Aplikasi Pengenalan Wajah Dengan Metode Orthogonal Laplacianfaces.

Eko Prasetyo (2011) Pengolahan Citra Digital dan Aplikasinya Menggunakan Matlab secara blackbox, scenario pengujian dan pengujian fungsional.

Mengingat masih adanya ketidaksempurnaan yang masih ada dalam sistem absensi ini serta demi kepentingan pengembangan sistem ini sendiri, maka dapat diberikan beberapa saran - saran yang mungkin dapat dipertimbangkan :

1. Pencahayaan saat penyimpanan dan pengenalan wajah sangatlah penting dan perlu diadakan pengujian lebih lanjut tentang batasan pencahayaan yang baik.

2. Pada saat face recognition dilakukan menggunakan webcam, sebaiknya tidak terlalu banyak gangguan di belakang pengguna (noise).

Jogiyanto H.M. 2001. Analisis dan Desain. New Jersey Prentice Hall.

Mcleod, Raymond (2001). Sistem Informasi Manajemen Versi Bahasa Indonesia, Edisi ketujuh,Prenhallindo, Jakarta.

Munawar (2005). Pemodelan Visual Dengan UML, Edisi pertama, Graha Ilmu, Yogyakarta.

$\mathrm{Ni}$ Wayan Marti, (2009)Penarapan Subruang Orthogonal pada Pengenalan Wajah Menggunakan Laplacianfaces

Pramitasari Noviana (2009)Pengenalan citra wajah menggunakan algoritme VF15 dengan transfoemasi wavelet

Pressman, Roger S. (2005). Software Engineering $A$ practitioner's 
Approach Sixth Edition. New York : Mc-Graw-Hill.

Roseman M, Sedera W, Gable G (2001). Critical Success Factors of Process Modeling for Enterprise Systems. Proceedings of the Americas Conference on Information Systems, Boston, Massachusetts.

Sholiq (2006). Pemodelan Sistem Informasi Berorientasi Objek Dengan UML, Edisi pertama,Graha IImu, Yogyakarta.
Soelaiman, R (2006) Sistem Pengenalan Wajah dengan Penerapan Algoritma Genetika pada Optimasi Basis Eigenface dan Proyeksi Fisherface, Tesis Master, Universitas Indonesia.

Tri Mulyono, dkk (2012) Sistem Pengenalan Wajah Dengan Metode Eigenfaces dan Jaringan Saraf Tiruan (JST)

Yambor, W.S. (2000) Analysis of PCABased and Fisher DiscriminantBased Image Recognition Algorithms, Tesis of Master, Colorado State University. 